\title{
SOCIO-PSYCHOLOGICAL ASPECTS OF THE SELF-REALIZATION OF A TEACHER WITH THE INTERNAL TYPE OF MOTIVATION
}

\section{Kovalchuk Z. Ya.}

\section{INTRODUCTION}

Attention to the problem of self-realization of personality in modern psychology is caused by the relevance of issues related to the study of the internal activity of the individual, the maximum use of resources for the full disclosure of a human in the process of development and activity. The realization of oneself is seen as a necessary condition for the development of the individual and the development of society as a whole.

Since teachers are directly involved in the process of the formation of a mature individual, as well as future society, it is important to analyze and empirically prove their desire to be realized. It is interesting to study the role of motivation in the process of self-realization of the teacher's personality.

The decisive role in the study of this issue, both theoretically and practically, played the works of F. Taylor, the experiments of E. Mayo, the theory of A. Maslow, D. McClelland, F. Herzberg, L. Porter, E. Lawler, D. McGregor, V. Vrum, D. Pink and others. The works of scientists are reflected practically in different fields of human activity. However, not much attention has been paid to the education sector, since most of the research works were directed to the commercial sector in order to maximize profits. We know that the educational sector is engaged in solving other problems, so the results obtained by the scientists here can not be directly applied to education or management problems in this field ${ }^{1,2,3}$.

1 Артемова О.І. Професійна самореалізація особистості в сучасних умовах. URL: http://social-science.com.ua/article/186

2 Ричи Ш. Методика: Изучение мотивационного профиля личности. URL: http://www.hr-portal.ru/tool/metodika-izuchenie-motivacionnogo-profilya-lichnosti-shrichi-i-p-martin 


\section{Empirical Research}

85 people participated in our empirical study. 45 teachers are residing in the city of Lviv and 40 teachers are residing in the rural area of the Ivano-Frankivsk region. So, in particular, it is Kornytska secondary school of 1-3 degrees and Kolomyya secondary school № 3.of 1-3 degrees.

The following methods were used in psychological research:

1) the diagnostics of self-actualization of personality by A.V.Lazurkin in the adaptation of N.F. Kalina (SMOAL);

2) the study of the motivational profile of the individual (Sh. Richie and P. Martin) ${ }^{4}$;

3) the motivation of professional activity (K. Zemfir's technique in A. Rean's modification $)^{5}$;

4) the method of estimation of level of request (V.K. Gorbachevskyy) ${ }^{6}$;

5) the quality of life assessment scale by N.Ye. Vodopyanov ${ }^{7}$.

The first methodology, which examines the self-realization of the school staff (A.V. Lazurkin in the adaptation of N.F. Kalin (SMOAL) $)^{8}$, was interested for auothors because of the scales of time orientation, values, point of view on a human nature, the high need for knowledge, the desire for creativity or creativity autonomy, spontaneity of selfunderstanding, autosympathy contact scale, flexibility in communication.

To find out the types of motivation of teachers, the methods of studying the motivational profile of personality (Sh. Richie and P. Martin $)^{9}$, the technique of motivation of professional activity

\footnotetext{
${ }^{3}$ Лазукин А.В. Диагностика самоактуализации личности. URL: http://vsetesti.ru/195/

${ }^{4}$ Ричи Ш. Методика: Изучение мотивационного профиля личности. URL: http://www.hr-portal.ru/tool/metodika-izuchenie-motivacionnogo-profilya-lichnosti-shrichi-i-p-martin

5 Замфир К. Методика изучения мотивации профессиональной деятельности. URL: http://azps.ru/tests/tests2_zamfir.html

${ }^{6}$ Горбачевський В.K. Методика «Оцінка рівня домагань». URL: http://studcon.org/metodyka-vyvchennya-rivnya-domagan?page=1

7 Водопьянова Н.Е. Оценка уровня удовлетворенности качеством жизни. Водопьянова Н.Е. Психология здоровья. СПб.: Питер, 2005. С. 148-155.

8 Лазукин A.B. Диагностика самоактуализации личности. URL: http://vsetesti.ru/195/

${ }^{9}$ Ричи Ш. Методика: Изучение мотивационного профиля личности. URL: http://www.hr-portal.ru/tool/metodika-izuchenie-motivacionnogo-profilya-lichnosti-shrichi-i-p-martin
} 
(K. Zemfir in A. Rean's modification $)^{10}$ and "Assessment of the level of desire" K. Gorbachevsky ${ }^{11}$ were applied.

Thus, the method of studying the motivational profile of personality (Sh. Richie and P. Martin) contains 33 statements, while each question contains four options of answers (a, b, c, d) between which, after careful reading, 11 points should be allocated. Using a special table, the score for each scale is calculated. The methodology contains 12 scales, which are also actively used in the study.

The concept of internal and external motivation makes the base for the methodology of professional activity motivation (K. Zemfir in A. Rean's modification). In this test, external motivation is differentiated into external positive and external negative. Accordingly, the methodology contains 3 rating scales.

The methodology "Assessment of the level of desire" by V.K. Gorbachevskyy is used to diagnose the components of a motivational structure that is related to the level of dersire. It contains 42 statements where it is needed to assess the degree of agreement or disagreement with them. The isolated components are a potential motivational structure that emerges in the course of a task. The estimates of each component of a person's motivational structure make it possible to form a personal profile of the respondent, indicating quantitative indicators and ratios of the proposed components.

It has been interesting for authors to investigate teachers' satisfaction with their lives, which will influence motivation and desire for self-fulfillment. For this purpose, the method of "The Scale of Quality of Life" by Vodopyanova was used ${ }^{12}$.The questionnaire contains 36 questions that show satisfaction in the following categories of individual life: work, personal achievement, health, communication with close people, support (internal and external - social), optimism, tension (physical and psychological discomfort), self-control, negative emotions (mood).

10 Замфир К. Методика изучения мотивации профессиональной деятельности. URL: http://azps.ru/tests/tests2_zamfir.html

${ }^{11}$ Горбачевський В.К. Методика «Оцінка рівня домагань». URL: http://studcon.org/metodyka-vyvchennya-rivnya-domagan?page $=1$

12 Водопьянова Н.Е. Оценка уровня удовлетворенности качеством жизни. Водопьянова Н.Е. Психология здоровья. СПб.: Питер, 2005. С. 148-155. 
The results of descriptive statistics allow the auhors to state the average meaning of each indicator for a group of subjects with the internal motivation.

Thus, analyzing the average values of teachers' self-realization, it can be seen that the most important for their self-realization is contact, flexibility in communication and autosympathy.

But the least important is time orientation, creativity and autonomy.

Table 1

\section{Descriptive statistics for the respondent group} with the internal type of motivation

\begin{tabular}{|l|c|c|c|}
\hline & $\mathrm{N}$ & $\mathrm{M}$ & $S D$ \\
\hline Time orientation & 41 & 5,63415 & 1,57728 \\
\hline Values & 41 & 8,17073 & 2,04820 \\
\hline View on a human nature & 41 & 7,90244 & 2,26721 \\
\hline The need for cognition & 41 & 7,34146 & 1,91846 \\
\hline Creativity & 41 & 6,48780 & 1,62975 \\
\hline Autonomy & 41 & 6,82927 & 2,30111 \\
\hline Spontaneity & 41 & 12,39024 & 2,39664 \\
\hline Self-understanding & 41 & 14,53659 & 2,92487 \\
\hline Autosympathy & 41 & 19,95122 & 3,89840 \\
\hline Contactability & 41 & 22,70732 & 3,64173 \\
\hline $\begin{array}{l}\text { Flexibility in } \\
\text { communication }\end{array}$ & 41 & 21,65854 & 4,07191 \\
\hline
\end{tabular}

This indicates that for teachers, contact, flexibility in communication and autosympathy plays the most important role in their self-realization. On the way to their self-realization, teachers are capable of establishing of long-lasting and friendly relationships with others, capable of adequate self-expression and self-disclosure in communication. However, time orientation, creativity, and autonomy are not important for successful teacher self-realization. This indicates that there is little need to strive for creativity in the work, self-support or internal motivation. Moreover, teachers with the internal type of motivation are not characterized by a focus on the present, that is, "here and now" and this does not interfere with their self-realization.

In terms of motivation, the results of descriptive statistics allow the authors to speak about such important indicators as: the need for 
material security, good working conditions, recognition and selfimprovement.

At the same time, the need for stable interaction is the least expressed.

Table 2

Descriptive statistics for the respondent group with the internal type of motivation

\begin{tabular}{|l|c|c|c|}
\hline \multicolumn{1}{|c|}{ Indexes } & $\mathrm{N}$ & $\mathrm{M}$ & $S D$ \\
\hline The need for material security & 41 & 31,41463 & 5,42206 \\
\hline $\begin{array}{l}\text { The need for good working } \\
\text { conditions }\end{array}$ & 41 & 31,39024 & 5,22914 \\
\hline The need for a clear structure of work & 41 & 29,58537 & 4,90396 \\
\hline The need for social contacts & 41 & 27,34146 & 4,18097 \\
\hline The need for stable interaction & 41 & 25,92683 & 3,01156 \\
\hline The need for recognition & 41 & 31,85366 & 3,88948 \\
\hline The need for achievement & 41 & 29,26829 & 3,89887 \\
\hline The need for power & 41 & 29,34146 & 5,76025 \\
\hline The need for change & 41 & 27,63415 & 3,58299 \\
\hline The need to be creative & 41 & 29,80488 & 3,48008 \\
\hline The need for self-improvement & 41 & 31,46341 & 4,59400 \\
\hline $\begin{array}{l}\text { The need for interesting community } \\
\text { service }\end{array}$ & 41 & 29,48780 & 4,19596 \\
\hline
\end{tabular}

Meanwhile, a motivator for educators with the internal type of motivation is a job that has a good set of benefits and allowances. Furthermore it is important for them to have comfort in the workplace, that is, an emotionally comfortable and clean workplace, where there is quiet and cozy atmosphere. Otherwise,the internal motivation will decrease if you have to perform professional duties in a cold or dirty area, and thus, the productivity will decrease. The need for recognition should be ensured by the positive appreciation and respect from colleagues and leadership for their respective merits, achievements and successes. The possibility of self-improvement can be a kind of motivator either, that can be satisfied through various trainings, courses, workshops. It can be a possibility to learn something new and to improve knowledge, skills and abilities. 
The most significant indicators of the assessment of the level of teacher's desire are also determined. So, in particular, these are indicators such as internal motivation, initiative, significance and regularity of results. The least important is the assessmentof the level of achievement.

Table 3

\section{Descriptive statistics for the respondent group with the internal type of motivation}

\begin{tabular}{|l|c|c|c|}
\hline \multicolumn{1}{|c|}{ Indexes } & $\mathrm{N}$ & $\mathrm{M}$ & $S D$ \\
\hline The internal motive & 41 & 12,78049 & 2,63166 \\
\hline The cognitive motive & 41 & 10,53659 & 3,27183 \\
\hline The motive of avoidance & 41 & 10,97561 & 3,57413 \\
\hline The competitive motive & 41 & 10,85366 & 2,91171 \\
\hline The motive of activity change & 41 & 10,58537 & 3,16998 \\
\hline Self-esteem motive & 41 & 10,24390 & 2,81763 \\
\hline The significance of the results & 41 & 12,02439 & 2,93673 \\
\hline The complexity of the task & 41 & 8,39024 & 2,35455 \\
\hline Willful effort & 41 & 10,12195 & 3,01824 \\
\hline Assesment of the level of achievement & 41 & 7,92683 & 2,32798 \\
\hline Assesment of the potential & 41 & 11,70732 & 2,32641 \\
\hline The set level of effort mobilization & 41 & 10,17073 & 2,94026 \\
\hline The expected level of result & 41 & 7,70732 & 2,12419 \\
\hline The regularity of the results & 41 & 11,09756 & 2,64391 \\
\hline Initiative & 41 & 12,00000 & 2,22486 \\
\hline
\end{tabular}

This indicates that the level of desire is directly related to the process of the activity.It is generalized and expressed through the involvement in the task itself. The ability to take own initiative in the work, to express visions on issues that arise during the work process, while understanding and relying on personal ability in order to achieve the goal are of the great importance.

Analyzing the average values of the quality of life of the respondents, it can be stated that special attention is paid to personal achievements and communication with close people. At the same time, optimism, self-control and negative emotions are the least manifested. 
Table 4

Descriptive statistics for the respondent group with the internal type of motivation

\begin{tabular}{|l|c|c|c|}
\hline \multicolumn{1}{|c|}{ Indexes } & $\mathrm{N}$ & $\mathrm{M}$ & $\mathrm{SD}$ \\
\hline Work & 41 & 23,56098 & 6,50788 \\
\hline Personal achievements & 41 & 24,60976 & 5,56272 \\
\hline Health & 41 & 23,95122 & 5,68309 \\
\hline Communication with close people & 41 & 24,58537 & 6,06208 \\
\hline Support & 41 & 23,63415 & 5,18052 \\
\hline Optimism & 41 & 22,09756 & 4,02371 \\
\hline Tension & 41 & 23,78049 & 6,09308 \\
\hline Self-control & 41 & 22,36585 & 4,38609 \\
\hline Negative emotions & 41 & 22,29268 & 4,22637 \\
\hline
\end{tabular}

Descriptive statistics indicates that they seek mutually beneficial contact with people, try to have self-disclosure, and are not susceptible to falsehood. However, for better self-realization, they need to work with a full set of benefits and allowances. In doing so, they are able to exert more effort and time to meet this need. Teachers are characterized by initiative and awareness of their own abilities to achieve the goal, which also indicates their internal motivation.

There are also relationships between the indexes of selfactualization and other psychological characteristics.

According to the results of the study, it can be concluded that the greater the need for material support $(r=0,33$ at $p<0,05)$, the internal motive $(r=0,33$ at $\mathrm{p}<0,05)$ is, the greater the time orientation is. However, the smaller the need for achievement $(r=-0.37$ at $p<0.05)$ and the motive of activity change $(r=-0.31$ at $p<0.05)$ is, the greater the time orientation is.

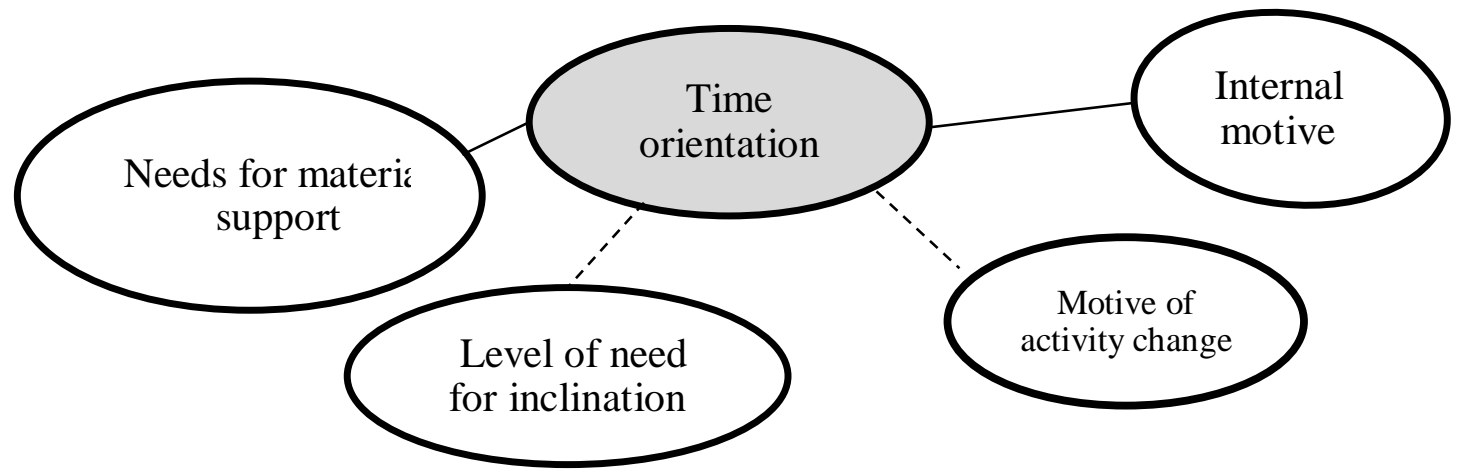

Fig. 1. Correlational connections on a scale "Time Orientation" 
It is proved that the greater the avoidance motive ( $\mathrm{r}=0.44$ at $\mathrm{p}<0.05)$ and the competitive motive $(\mathrm{r}=0.32$ at $\mathrm{p}<0.05)$ is, the higher values the respondents will have. However, the smaller the motive of activity change $(r=-0.36$ at $p<0.05)$ is, the higher the values will be (see Fig. 2).

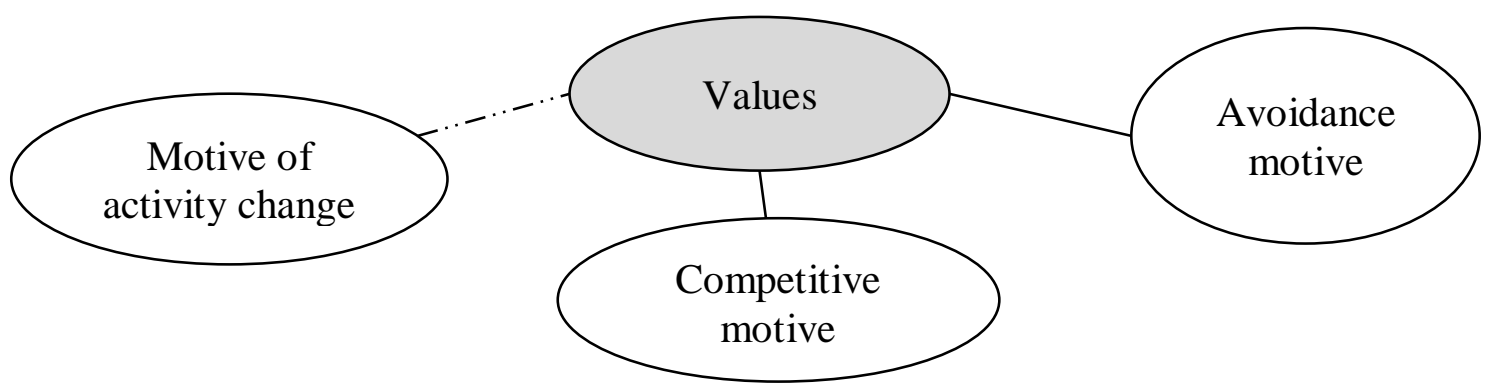

Fig. 2. Correlational connections according to the scale "Values"

Correlation results suggest that the greater the internal motive $(\mathrm{r}=0.46$ at $\mathrm{p}<0.05)$ and communication with close people $(\mathrm{r}=0.32$ at $\mathrm{p}<0.05)$ is, the greater the views on human nature will be. However, the lower the expected level of results will be $(r=-0.32$ at $\mathrm{p}<0.05)$, the greater the views on human nature will be.

Table 5

Correlational connections according to the scale

"Level of Views on a Human Nature"

\begin{tabular}{|l|c|c|}
\hline \multicolumn{1}{|c|}{ The name of the scales } & Значення $\mathrm{r}$ & $\mathrm{P}$ \\
\hline The internal motive & 0,46 & 0,05 \\
\hline Communication with the close people & 0,32 & 0,05 \\
\hline Expected level of results & $-0,32$ & 0,05 \\
\hline
\end{tabular}

It was also found out that the smaller the need for work ( $\mathrm{r}=-0.37$ at $\mathrm{p}<0.05$ ) is, the greater the need for cognition is.(see Fig. 2.3).

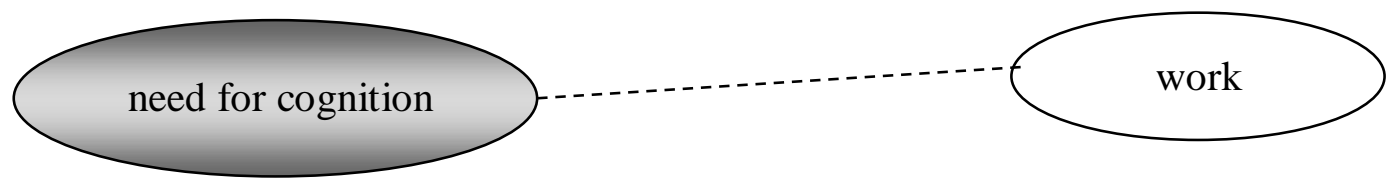

Fig. 3. Correlational connections according to the scale "Need for cognition" 
The more autonomy teachers exhibit, the more internal motivation will be observed $(\mathrm{r}=0.32$ for $\mathrm{p}<0.05)$, but the smaller the motive of activity change is $(r=-0.36$ for $\mathrm{p}<0.05)$ (see Fig. 2.4).

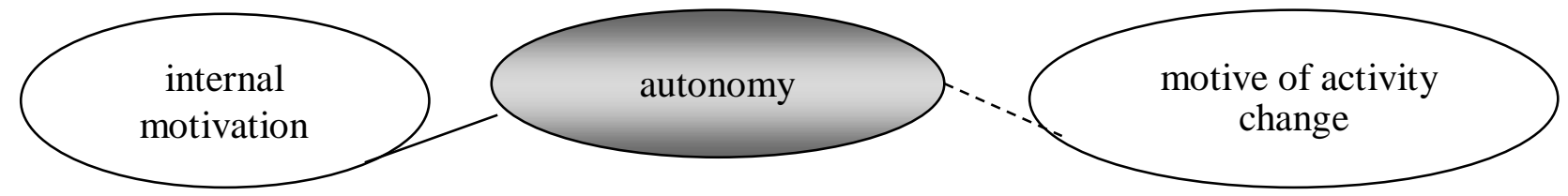

Fig. 4. Correlational relations according to the scale "Autonomy"

By the result of the correlation, we can conclude that with a decrease in the motive of activity change $(r=-0,40$ at $p<0,05)$, the manifestation of spontaneity increases.

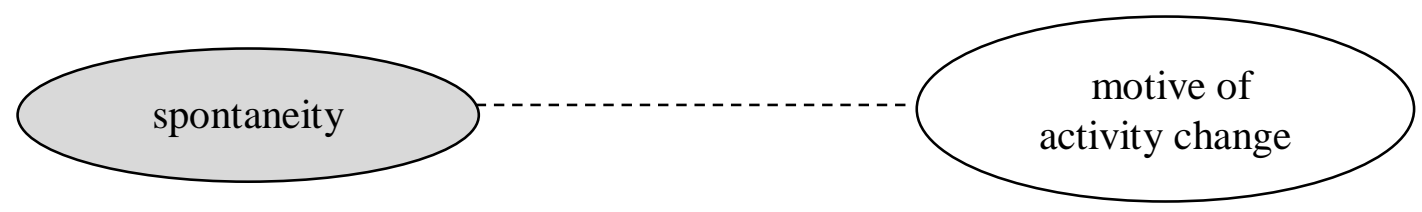

Fig. 5. Correlational connections according to the "Spontaneity" scale

The greater the need for power $(r=0.32$ for $\mathrm{p}<0.05)$, the motive for avoidance $(r=0.32$ for $\mathrm{p}<0.05)$ and the smaller the motive for change in activity will be $(\mathrm{r}=-0.33$ for $\mathrm{p}<0.05)$, the more self-understanding will be manifested (see Table 2.8).

Table 6

\section{Correlational connections according to the scale}

"Self-understanding"

\begin{tabular}{|l|c|c|}
\hline \multicolumn{1}{|c|}{ The name of the scales } & Meaning $\mathrm{r}$ & $\mathrm{P}$ \\
\hline The need for power & 0,32 & 0,05 \\
\hline The motive for avoidance & 0,32 & 0,05 \\
\hline The motive of activity change & $-0,33$ & 0,05 \\
\hline
\end{tabular}

Also, according to the results of the study, it is concluded that with an increase of the internal motive $(r=0.48$ at $\mathrm{p}<0.05)$, the expected level of results decreases $(r=-0.34$ at $\mathrm{p}<0.05)$, and autosympathy increases. 


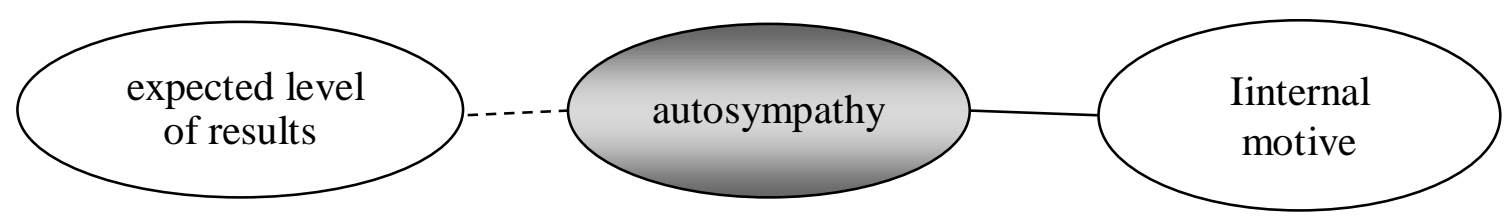

Fig. 6. Correlational connections according to the scale "Autosympathy"

It is also found out in the study that the more the avoidance motive is pronounced $(r=0.60$ at $p<0.05)$, the greater the contact is.

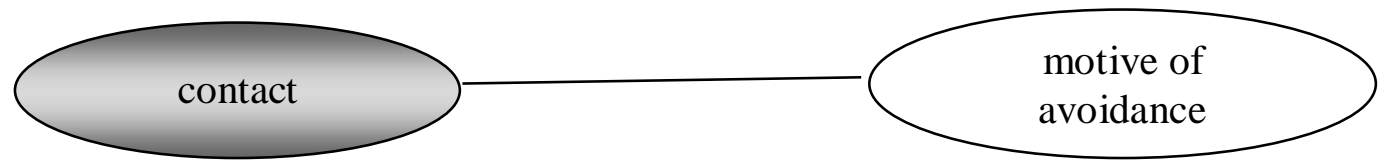

Fig. 7. Correlational connections according to the scale "Contact"

The authors have shown that with increasing level of communication with close people $(r=0.35$ at $\mathrm{p}<0.05)$, flexibility in communication increases, and with decreasing of expected level of result $(\mathrm{r}=-0.33$ at $\mathrm{p}<0.05)$ increases the flexibility in communication.

Correlational connections according to the scale "Flexibility in Communication"

\begin{tabular}{|l|c|c|}
\hline \multicolumn{1}{|c|}{ The name of the scales } & Meaning $\mathrm{r}$ & $\mathrm{P}$ \\
\hline Communication with close people & 0,35 & 0,05 \\
\hline The expected level of result & $-0,33$ & 0,05 \\
\hline
\end{tabular}

It is determined that the less pronounced the need for work $(r=-0.57$ at $p<0.05)$ is, the greater the need for social contacts will be manifested.

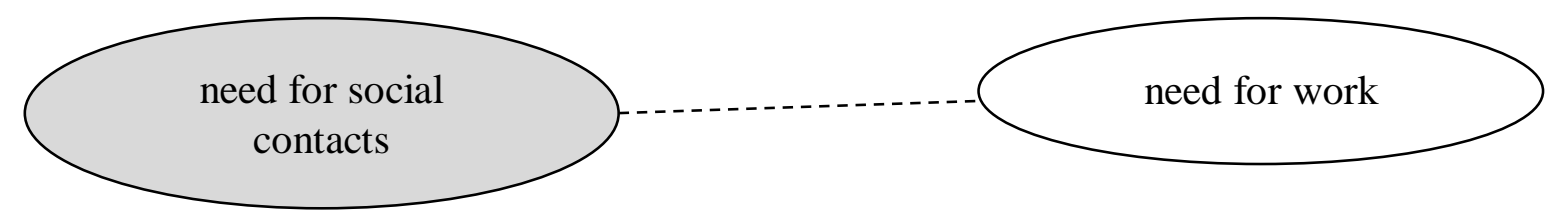

Fig. 8. Correlational connections according to the scale "The need for social contacts" 
The smaller the need for work is $(r=-0.35$ at $\mathrm{p}<0.05)$, the greater the need for stable interaction will be.

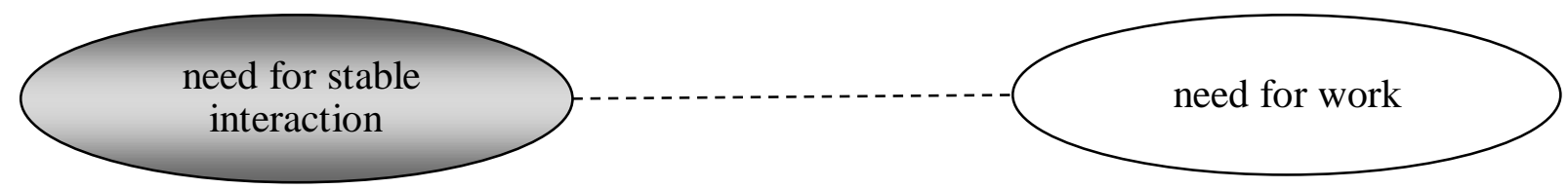

Fig. 9. Correlational connections according to the scale "The need for stable interaction"

It is stated that the greater the avoidance motive $(r=0.31$ at $\mathrm{p}<0.05)$ will be, and the smaller the personal achievement $(\mathrm{r}=-0.31$ at $\mathrm{p}<0.05$ ) will be, the greater the need for creativity will be.

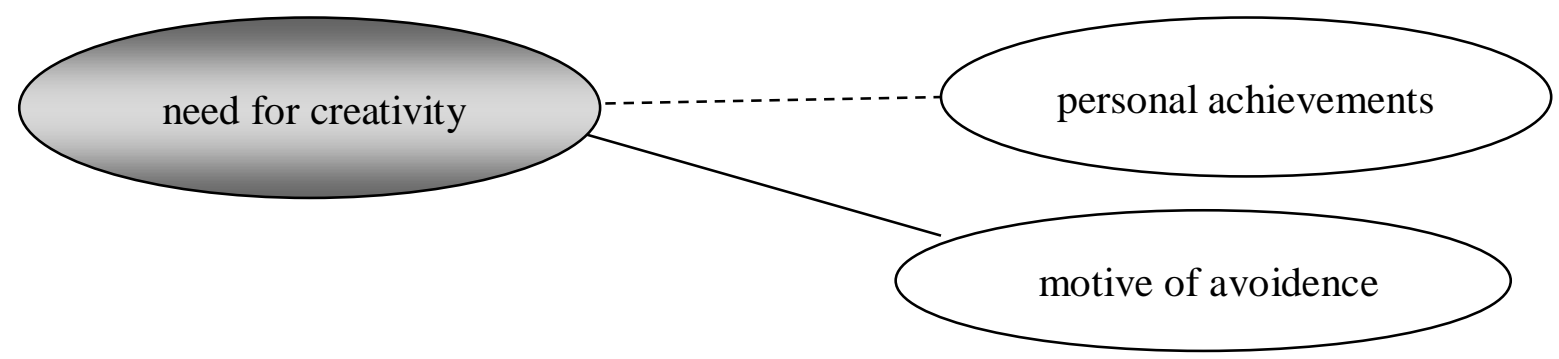

Fig. 10. Correlational connections according to the scale "The need for creativity"

It is determined that the smaller the cognitive motive ( $\mathrm{r}=-0.32$ at $\mathrm{p}<0.05)$ and the significance of the results $(\mathrm{r}=-0.34$ at $\mathrm{p}<0.05)$ will be, the greater the need for self-improvement will be. However, the greater the estimate of one's potential $(r=0.32$ at $\mathrm{p}<0.05)$ and communication with close people $(r=0.34$ at $p<0.05)$ will be, the greater the need for self-improvement will be.

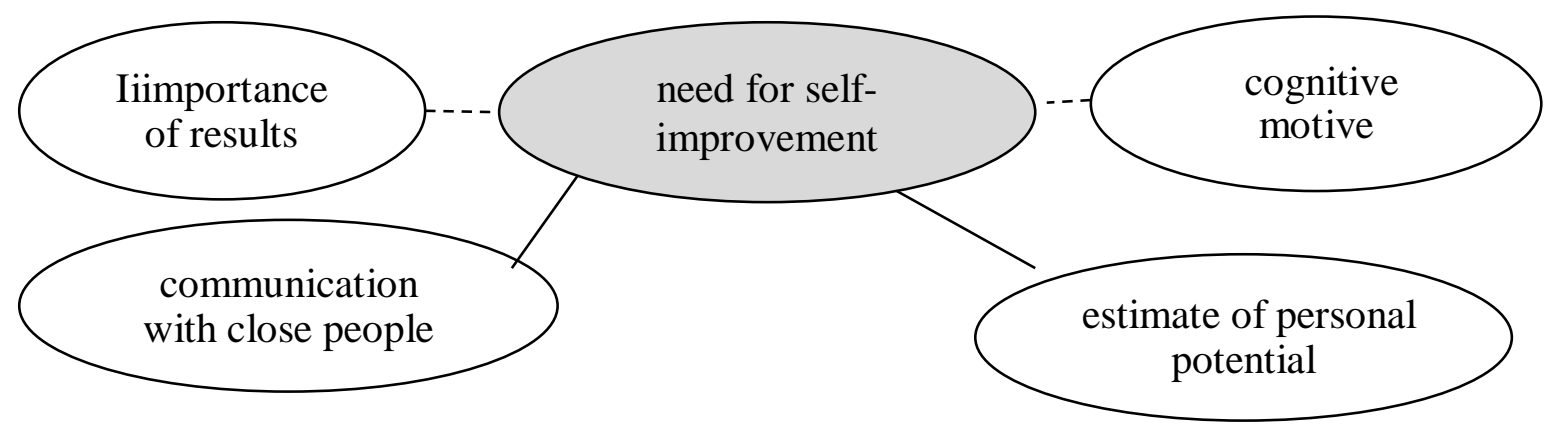

Fig. 11. Correlational connections according to the scale "The need for self-improvement" 
The greater the regularity of results $(r=0.44$ at $p<0.05)$ and work $(\mathrm{r}=0.32$ at $\mathrm{p}<0.05)$ will be, the greater the need for social contacts will be.

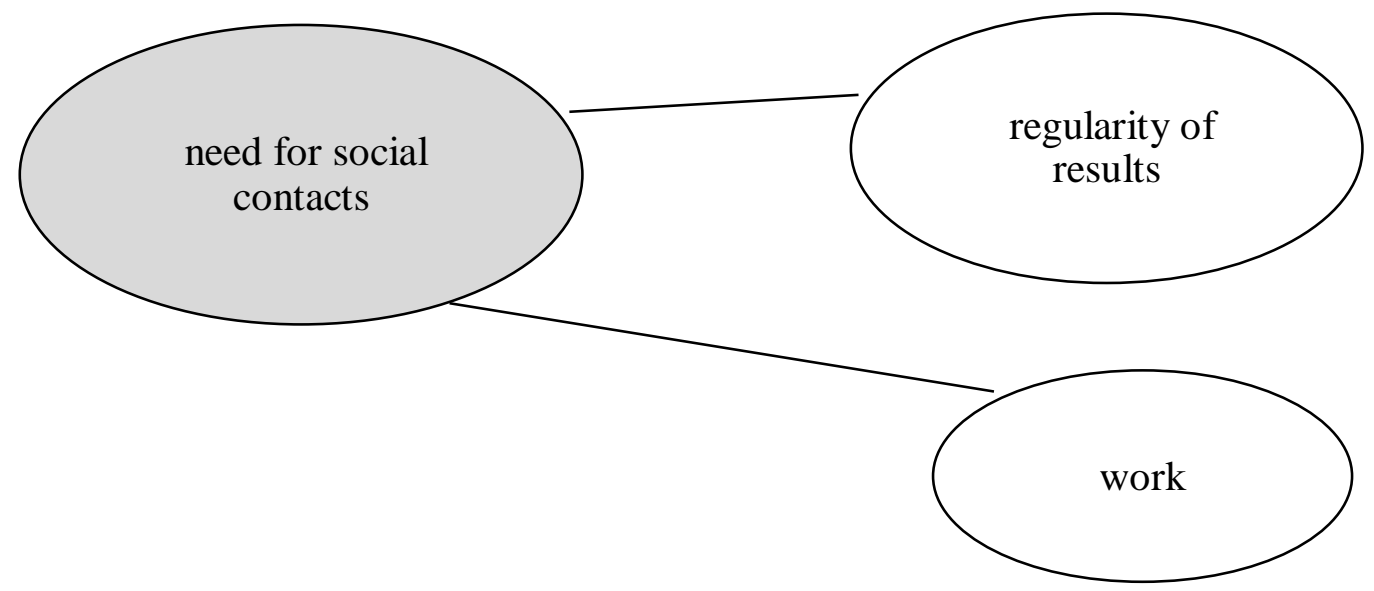

Fig. 12. Correlational connections according to the scale "The need for social contacts"

The greater the time orientation $(r=0,34$ at $\mathrm{p}<0,05)$, the view on a human nature $(r=0,47$ at $\mathrm{p}<0,05)$, autonomy $(\mathrm{r}=0,32$ at $\mathrm{p}<0,05)$ autosympathy $(\mathrm{r}=0.48$ at $\mathrm{p}<0.05)$, and the regularity of results $(\mathrm{r}=0.33$ at $\mathrm{p}<0.05$ ) will be, the greater the internal motive will be.

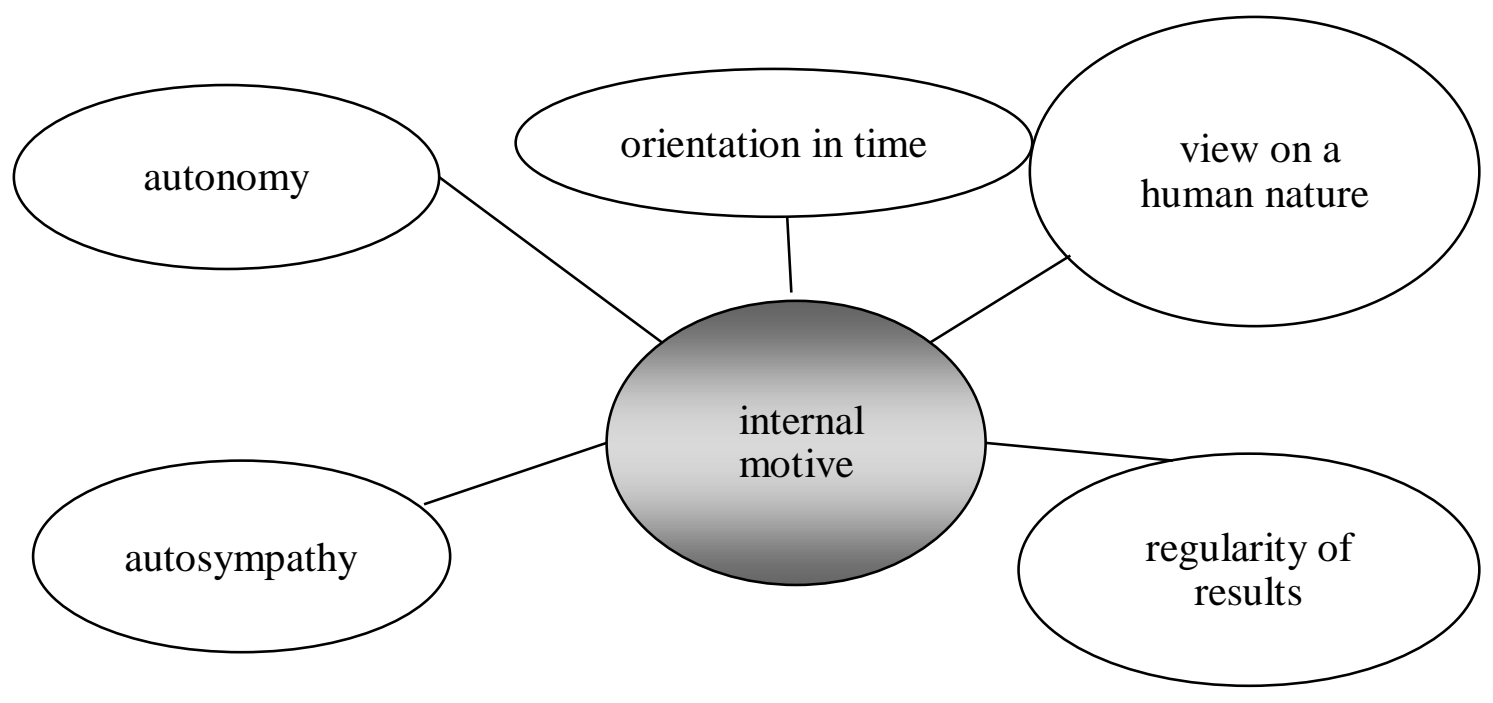

Fig. 13. Correlational connections according to the scale "The internal motive" 
It is found out that with increasing values ( $r=0.44$ at $p<0.05)$, selfunderstanding $(\mathrm{r}=0.31$ at $\mathrm{p}<0.05)$, contact $(\mathrm{r}=0.35$ at $\mathrm{p}<0.05)$, personal achievements $(r=0.31$ at $\mathrm{p}<0.05)$, communication with close people $(r=0.31$ at $p<0.05)$ and optimism $(r=0.43$ at $p<0.05)$, motives of avoidance are increasing. The relationship between internal motivation $(\mathrm{r}=-0.37$ at $\mathrm{p}<0.05)$ and the motive of avoidance is inversely proportional.

Table 8

\section{Correlational connections according to the scale}

"The motive of avoidance"

\begin{tabular}{|l|c|c|}
\hline \multicolumn{1}{|c|}{ The name of the scales } & Meaning $\mathrm{r}$ & $\mathrm{P}$ \\
\hline Values & 0,44 & 0,05 \\
\hline Selfunderstanding & 0,31 & 0,05 \\
\hline Contact & 0,35 & 0,05 \\
\hline Personal achievements & 0,31 & 0,05 \\
\hline Communication with close people & 0,31 & 0,05 \\
\hline Optimism & 0,43 & 0,05 \\
\hline Internal motivation & 0,37 & 0,05 \\
\hline
\end{tabular}

The relationship between values $(r=0.31$ at $p<0.05)$ and competitive motive is directly proportional.

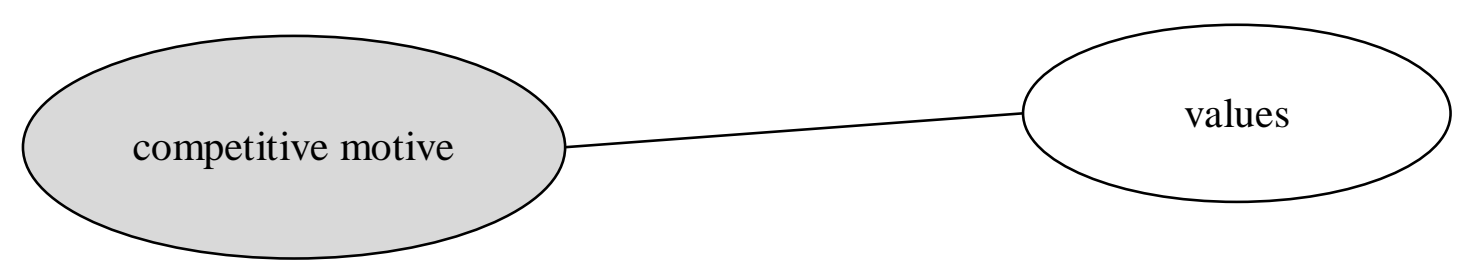

Fig. 14. Correlational connections according to the scale "Competitive motive"

It is determined that the smaller the level of time orientation $(\mathrm{r}=-0,31$ at $\mathrm{p}<0,05)$, values $(\mathrm{r}=-0,36$ at $\mathrm{p}<0,05)$, autonomy $(\mathrm{r}=-0,36$ at $\mathrm{p}<0.05)$, spontaneity $(\mathrm{r}=-0.40$ at $\mathrm{p}<0.05)$, self-understanding $(\mathrm{r}=-0.33$ at $\mathrm{p}<0.05)$, recognition needs $(\mathrm{r}=-0.32$ at $\mathrm{p}<0.05)$ is, the lower the level of the motive of activity change is. 


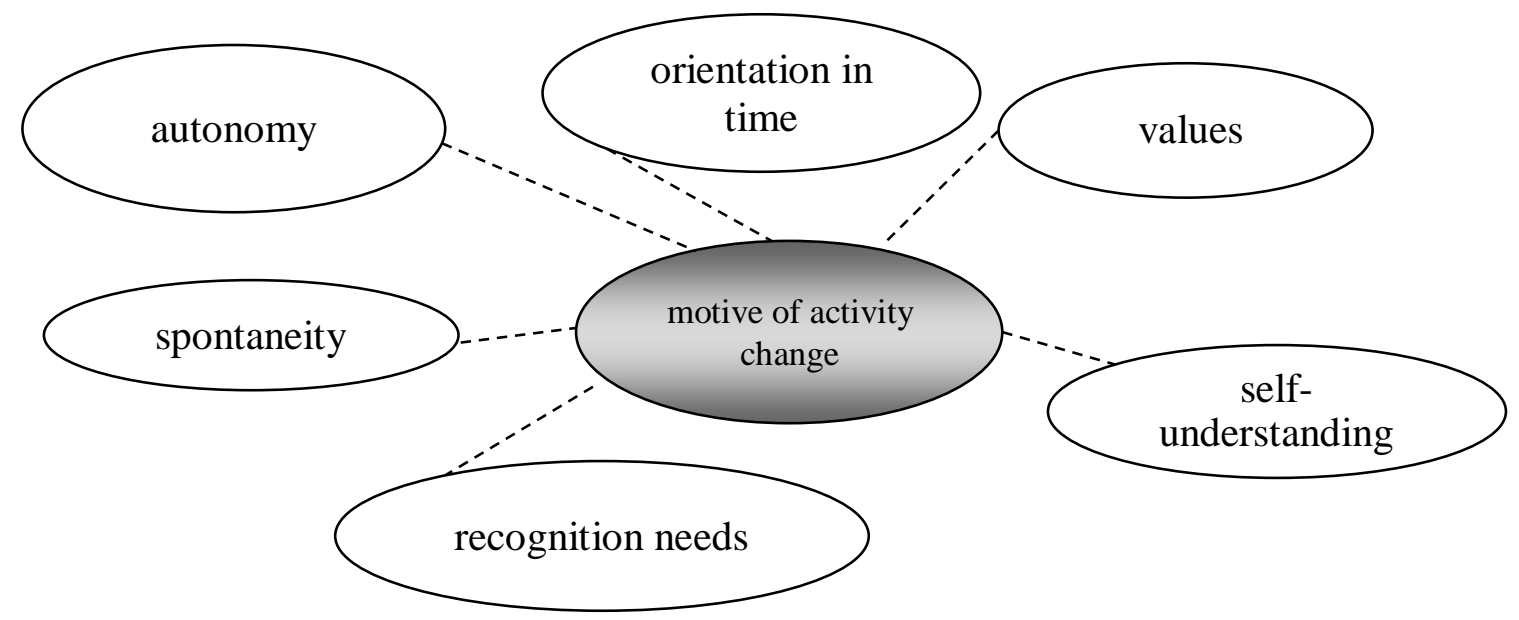

\section{Fig. 15. Correlational connections according to the scale "The motive of activity change"}

It is seen that the need for creativity $(r=0.31$ at $p<0.05)$ also directly affects the self-respect motive. However, when the need for power and influence decreases $(r=-0.39$ at $p<0.05)$, the motive of selfrespect increases.

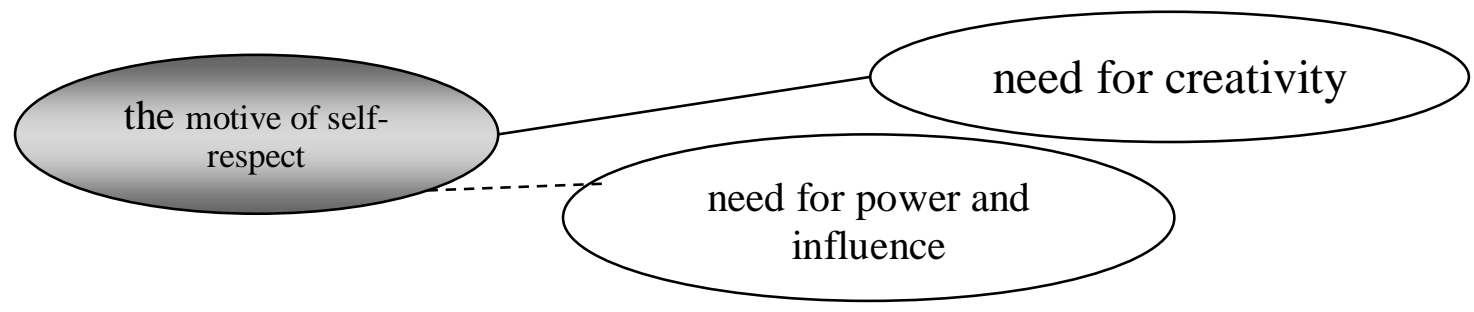

Fig. 16. Correlational connections according to the scale "The motive of self-respect"

The value of the results also increases with the increase of personal achievements $(r=0,33$ at $\mathrm{p}<0,05)$.

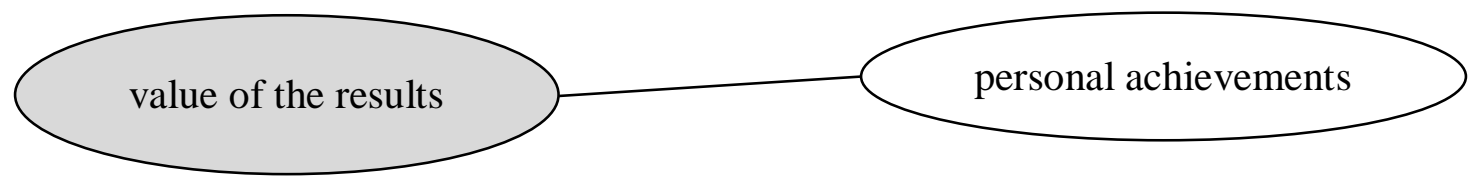

Fig. 17. Correlational connections according to the scale "The value of the results" 
The volition effort of the study also increases with increase of the communication with loved ones $(r=0.34$ at $\mathrm{p}<0.05)$ and the level of outcome $(r=0.35$ at $p<0.05)$

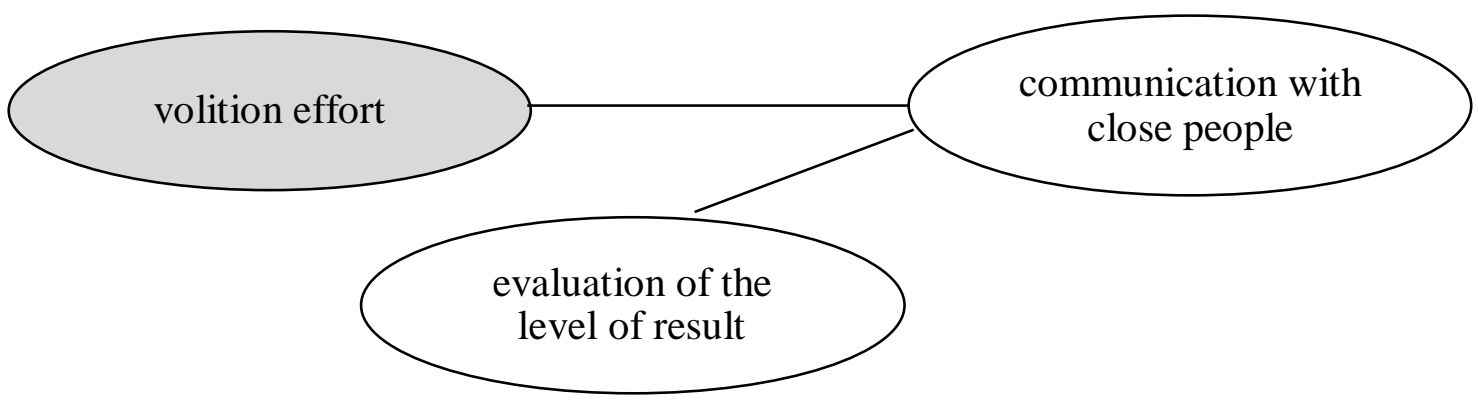

Fig. 18. Correlational connections according to the scale "Volition effort"

Initiative increases with the need for diversity and change $(r=0.40$ at $\mathrm{p}<0.05)$ and with the decrease of the regularity of result $(\mathrm{r}=-0.34$ at $\mathrm{p}<0.05)$.

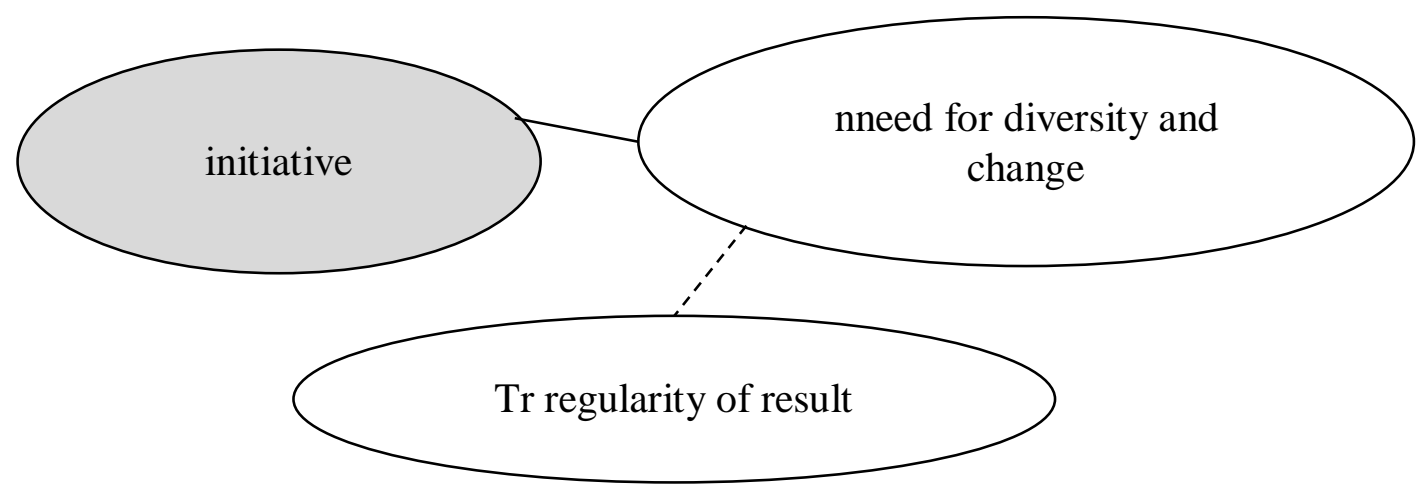

Fig. 19. Correlational connections according to the scale "Initiative"

According to empirical data of the study, the communication with close people improves with an increase in the level of views on a human nature $(\mathrm{r}=0,32$ at $\mathrm{p}<0,05)$, flexibility in communication $(\mathrm{r}=0,35$ at $\mathrm{p}<0,05)$, the need for interesting socially useful work $(\mathrm{r}=0,31$ at $\mathrm{p}<0,05)$, external positive motivation $(\mathrm{r}=0,30$ at $\mathrm{p}<0,05)$. Communication with close people improves with the decrease in the value of results $(r=-0,31$ at $p<0,05)$. 
Correlational connections according to the scale

"Communication with close people"

\begin{tabular}{|c|c|c|}
\hline The name of the scales & Meaning $\mathrm{r}$ & $\mathrm{P}$ \\
\hline Views on a human nature & 0,32 & 0,05 \\
\hline Flexibility in communication & 0,35 & 0,05 \\
\hline Need for interesting community service & 0,31 & 0,05 \\
\hline External positive motivation & 0,30 & 0,05 \\
\hline The level of significance of the results & $-0,31$ & 0,05 \\
\hline
\end{tabular}

The level of tension increases with the need for recognition $(\mathrm{r}=\mathrm{at}$ $\mathrm{p}<0,05)$, external negative motivation $(\mathrm{r}=$ at $\mathrm{p}<0,05)$, self-esteem motivation $(r=$ at $\mathrm{p}<0,05)$.

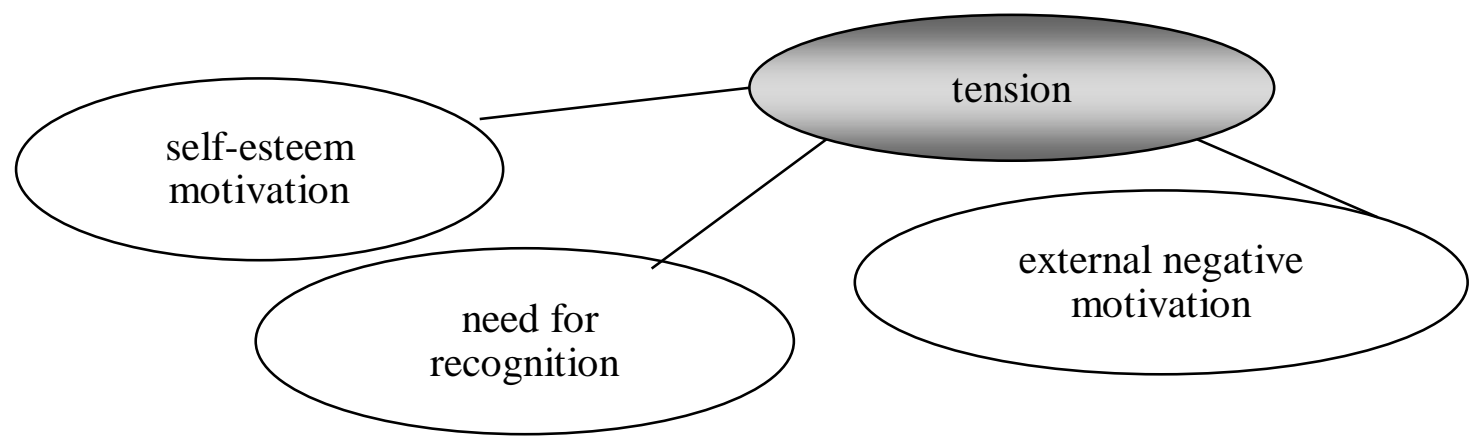

Fig. 20. Correlational connections according to the scale "Tension"

Analyzing the correlation relationships, it is noticed that negative emotions increase with the increase in the avoidance motive $(r=0.42$ at $\mathrm{p}<0.05)$ and regularity of results $(\mathrm{r}=0.33$ at $\mathrm{p}<0.05)$.

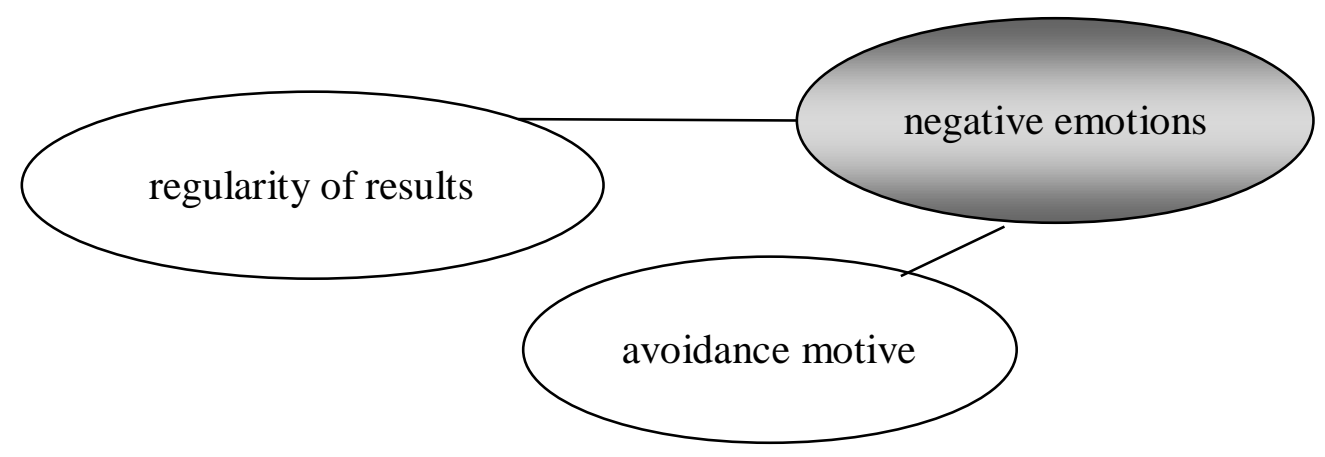

Fig. 21. Correlational connections according to the scale "Negative emotions" 
The greater the need for interesting community service is $(r=0.31$ at $\mathrm{p}<0.05)$ and internal motive is $(\mathrm{r}=0.31$ at $\mathrm{p}<0.05)$, the greater the need for personal achievement is. The smaller the need for change $(\mathrm{r}=-0.37$ at $\mathrm{p}<0.05)$, the level of effort mobilization $(\mathrm{r}=-0.32$ at $p<0.05)$ and the initiative $(r=-0.34$ at $p<0.05)$ is, the greater the need for achievement is.

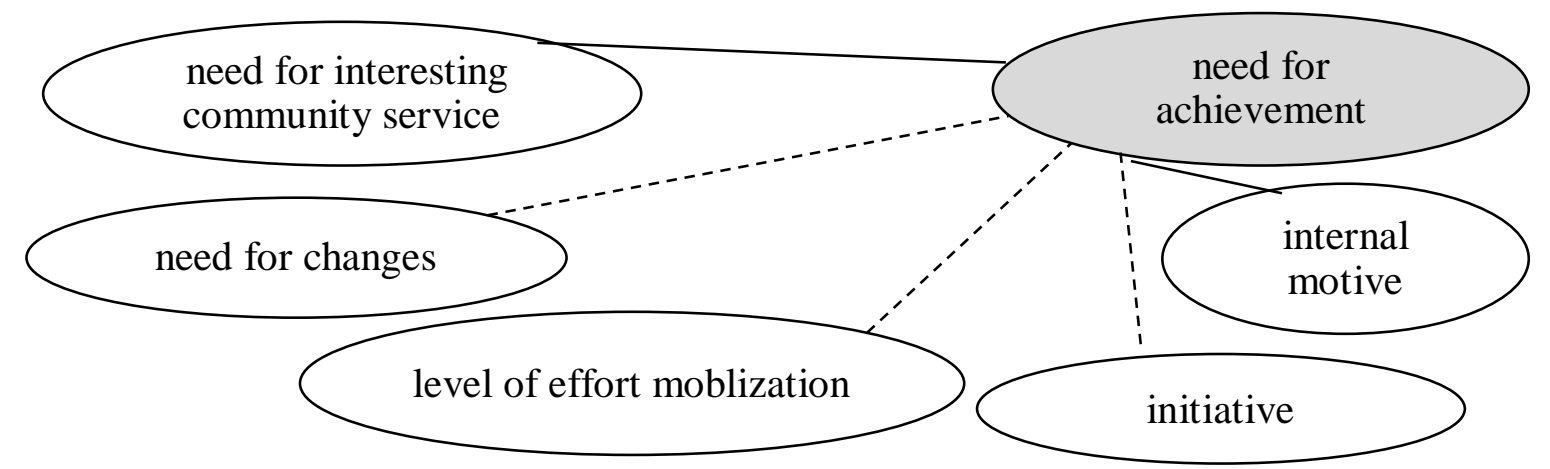

Fig. 22. Correlational connections according to the scale "The need of achievements"

Therefore, people with the internal type of motivation are characterized by living nowadays life ("here and now"). They are not inclined to postpone their lives for later or seek solutions to certain problems of the past. However, getting away from this lifestyle can be explained by a desire for achievements, when a person wants to work alone and the received results must be judged. That is, when a person is focused solely on his goal. However, when he reaches it, he will have a new one and so on without stopping.

It has also been concluded that people strive for a harmonious life and a healthy relationship with others. They have such values as goodness, beauty, uniqueness, excellence. They have no desire to manipulate people in their interests. The communication with close people having own will is important. They are always open to new impressions, are eager to learn something new and do not want to stop, however, the importance of work and workload does not allow them to be open to new things completely.

At the same time, they are afraid to show lower results than others, and pay more attention not to their personal results, but to the results of their colleagues. They do not have a spontaneous change of work, because they trust the world and are confident in themselves. Even with 
great trust in others, they do not forget their desires and needs, so they show their competitiveness, compare themselves with others and want to have an impact on them. In doing so, they are afraid of being worse at something.

Even so, they are passionate about the task they are performing and feel confident. That becomes a source of adequate self-esteem and selfawareness. Close communication with people is also important. They are open to new experiences and show self confidence. They are able to show competitiveness, compare themselves with others and want to have an impact on them. Fear of showing low results in work leads to negative emotions and tensions of individuals.

They have a manifestation of creativity in their work, but the right to make mistakes is important to them. Only then they will be able to set a more complex goal in their activities.

Thus, there is a correlation between time orientation as an indicator of self-realization, and the internal motive. There is also a direct link between the value of self-realization and the competitive motive and the motive of avoidance.

It has been established that teachers with different work experience have psychological differences. For comparison of the obtained data, comparative univariate analysis of variance (Scheffe test) at $\mathrm{p}<0,05$ was performed using indicators. For this purpose, three groups were distinquished: the first one - with work experience up to 10 years, the second one- up to 20 years and the third group with experience more than 20 years.

Thus, for the second group, the need for creativity is the most featured $(M=32,375)$. In the second place, the need for creativity plays an important role for the first group, that is, for teachers who have up to 10 years of experience $(M=28.118)$. The smallest role for the need in creativity is played for people who have experience more than 20 years, meaning group3 $(M=30,313)$.

Table 10

Scheffe Test for the scale "The need in creativity"

\begin{tabular}{|c|c|c|c|}
\hline $\begin{array}{c}\text { Comparison } \\
\text { of experience }\end{array}$ & $\{1\}-\mathrm{M}=28,118$ & $\{2\}-\mathrm{M}=32,375$ & $\{3\}-\mathrm{M}=30,313$ \\
\hline $0\{1\}$ & & $\mathbf{0 , 0 1 2 3 6 7}$ & 0,150665 \\
\hline $1\{2\}$ & $\mathbf{0 , 0 1 2 3 6 7}$ & & 0,331407 \\
\hline $2\{3\}$ & 0,150665 & 0,331407 & \\
\hline
\end{tabular}


The need for significance of results is most pronounced in the first group $(M=13,471)$, and the least important is the need for significance of results for the third group $(\mathrm{M}=10,563)$ ) (see Table 2.13).

Table 11

Scheffe Test for the scale "The ned for the significance of results"

\begin{tabular}{|c|c|c|c|}
\hline $\begin{array}{c}\text { Comparison of } \\
\text { experience }\end{array}$ & $\{1\}-\mathrm{M}=13,471$ & $\{2\}-\mathrm{M}=11,875$ & $\{3\}-\mathrm{M}=10,563$ \\
\hline $0\{1\}$ & & 0,393209 & $\mathbf{0 , 0 1 3 6 8 0}$ \\
\hline $1\{2\}$ & 0,393209 & & 0,535640 \\
\hline $2\{3\}$ & $\mathbf{0 , 0 1 3 6 8 0}$ & 0,535640 & \\
\hline
\end{tabular}

Support is determined to be very important for the first group, that is, for those under 10 years of experience $(M=26,000)$, for those under 20 , support plays a smaller role $(\mathrm{M}=22,813)$ and plays the least one for those with experience more than 20 years $(M=20,250)$.

Table 12

Scheffe Test for the scle "Support"

\begin{tabular}{|c|c|c|c|}
\hline $\begin{array}{c}\text { Comparison } \\
\text { of experience }\end{array}$ & $\{1\}-\mathrm{M}=26,000$ & $\{2\}-\mathbf{M}=20,250$ & $\{3\}-\mathrm{M}=22,813$ \\
\hline $0\{1\}$ & & $\mathbf{0 , 0 2 8 7 7 1}$ & 0,176430 \\
\hline $1\{2\}$ & $\mathbf{0 , 0 2 8 7 7 1}$ & & 0,474807 \\
\hline $2\{3\}$ & 0,176430 & 0,474807 & \\
\hline
\end{tabular}

Therefore, the need for creativity is of prior importance in the second group, that is, for teachers with up to 20 years of experience. This group of people has a creative attitude to life and work. The teachers are not afraid to experiment at their lessons, because they believe that this is the key to successful memorizing the material by students.

For the first group of teachers, that is, for those who have up to 10 years of work experience, the significance of the results is important. What matters to them is how useful the results of their own work are to them. Also, for the teachers who belong to the first group according to the performed distribution, their personal support and their own work plays an important role. 
At the same time, by means of comparative analysis on the $t-$ Student's criterion, the differences of internal - motivated teachers living in rural and urban areas are also established.

In order to compare the obtained data using the Student's t-test indicators, the two groups were identified: the first one is - rural residents and the second one is- urban residents.

Table 13

The results of comparative analysis according to the teachers' place of residence

\begin{tabular}{|l|c|c|c|c|}
\hline \multicolumn{1}{|c|}{ Indicators } & $\begin{array}{c}\text { Average } \\
\text { number for } \\
\text { people living } \\
\text { in the village }\end{array}$ & $\begin{array}{c}\text { Average } \\
\text { number for } \\
\text { people living } \\
\text { in the city }\end{array}$ & $\mathrm{t}$-value & $\mathrm{p}$ \\
\hline $\begin{array}{l}\text { The need for } \\
\text { material security }\end{array}$ & 33,21053 & 29,86364 & 2,04814 & 0,047321 \\
\hline $\begin{array}{l}\text { The need for } \\
\text { structured work }\end{array}$ & 28,47368 & 30,54545 & $-1,36334$ & 0,180595 \\
\hline $\begin{array}{l}\text { The need for } \\
\text { power }\end{array}$ & 28,57895 & 30,00000 & $-0,78390$ & 0,437833 \\
\hline $\begin{array}{l}\text { The need for self- } \\
\text { improvement }\end{array}$ & 30,84211 & 32,00000 & $-0,80116$ & 0,427892 \\
\hline $\begin{array}{l}\text { The need for } \\
\text { interesting } \\
\text { community } \\
\text { service }\end{array}$ & 28,42105 & 30,40909 & $-1,53846$ & 0,132012 \\
\hline $\begin{array}{l}\text { The motive of } \\
\text { activity change }\end{array}$ & 9,68421 & 11,36364 & $-1,73349$ & 0,090910 \\
\hline $\begin{array}{l}\text { The self-esteem } \\
\text { motive }\end{array}$ & 11,10526 & 9,50000 & 1,87548 & 0,068228 \\
\hline $\begin{array}{l}\text { Assessment of } \\
\text { personal potential }\end{array}$ & 12,63158 & 10,90909 & 2,51680 & 0,016065 \\
\hline $\begin{array}{l}\text { Personal } \\
\text { achievements }\end{array}$ & 22,68421 & 26,27273 & $-2,15117$ & 0,037717 \\
\hline
\end{tabular}

Thus, for those living in rural areas, indicators such as the need for financial support, self-esteem motive and the assessment of their potential are of greater importance. And for people living in the city - 
the need for structured work, the need for power, the need for selfimprovement, the need for interesting socially useful work, the motive of activity change and personal achievements play more important role.

Analyzing the results of the comparative analysis by the place of residence, it can be said that teachers living in rural areas place greater emphasis on material security. They also have a desire to set a more difficult goal in the same type of activity.

For people living in a city, the need for structured work becomes more important. Another characteristic of workers living in a city is the need for self-improvement, growth and development of the teacher as an individual. It is an indicator of freedom and the pursuit of independence. It is typical for them to have the desire to lead others, and this indicates a competitive tenacity of teachers.

Thus, for people with internal motivation, the need for selfimprovement will be greater for educators living in the city, and the need for financial support is more important for educators living in the village.

The analysis of factors allows to identify the groups of reasons that influence the work of teachers with the internal motivation.

To study the factor structure of the results obtained and the importance of the individual indicators, factor analysis was applied, using the principal component method (rotation of the Varimax axes). The decision on the number of factors was made on the basis of the analysis of the bar chart and the eigenvalues.

Thus, seven latent factors have been identified, which explain 56, $053 \%$ of the total variance of the data.

The first factor covers the following scales: "flexibility in communication" (0.808), spontaneity (0.758), autosympathy (0.881), and view on a human nature $(0.855)$. It was called "Self-realization". The factor explained $12.6 \%$ of the variance.

Explaining the result, it can be stated that for self-realization of teachers with the internal type of motivation, flexibility in communication, spontaneity, already conscious self-concept and ability to adequately express themselves in communication and lack of social stereotypes which is expressed through views on a human nature .

The second factor of "Communication with close people" includes: "work" (0.719), health (0.679), communication with relatives $(0.735)$ and support (0.670). This factor describes $10.585 \%$ of the variance. 
The findings suggest that communication with close people plays an important role for the respondents and should be present at work, expressed through support, and it influences health. This factor shows that the need for change can increase.

The fourth factor, "Need for structured work", contains the following scales: "need for good working conditions" $(-0,738)$, "need for structured work" $(0,626)$ and need for creativity $(-0,767)$. The factor explained $7.578 \%$ of the variance.

This result can be interpreted as the need for structured work of persons with the internal type of motivation. Such people want to be highly organized in their work. They want to know clearly what is required of them. It is not important for them to express their creativity and the need for good working conditions.

The fifth factor, "Level of intention" covers the following scales: "self-realization value" (0.599), "competitive motive" (0.688), and "activity change motive" (0.588), which explains $6.232 \%$ of the variance.

Interpreting this factor, it can be said that individuals are characterized by the importance of high results in the activities of other people, which will be important in self-realization.

The sixth factor was named "Self-control", which covers only the "self-control" scale (0.634). This factor describes $5.868 \%$ of the variance.

Self-control is characteristic of individuals with the internal type of motivation. They make easy decisions, but they have more obligations than they need to fulfill. It is very easy for individuals to adapt to new situations.

The seventh factor "The need for recognition" only covers the scale of "the need for recognition" (0.659). It described 5.254\% of the variance.

The need for recognition by the respondents will be accepted only when it sounds sincere and willing; otherwise, this praise may demotivate the teacher.

\section{SUMMARY}

Thus, after conducting a survey using descriptive statistics, it is dtermined that the individuals with the internal motivation possess adequate self-disclosure and the good working conditions are of the primary importanc for them. They come up with their own suggestions and ideas for solving some work problems.

Respondents living in rural areas attach greater importance to material security. They boldly set complex goals and achieve them. 
More important for city teachers is the need for structured work and selfimprovement, which is an indicator of freedom and the desire for independence. The desire to lead is typical for them, and this indicates a competitive tenacity of teachers.

The prospect of further research will be to analyze the results of an empirical study of teachers' self-realization with external motivation and to compare the results by demographic data.

\section{REFERENCES}

1. Артемова О.I. Професійна самореалізація особистості в сучасних умовах. URL: http://social-science.com.ua/article/186

2. Водопьянова Н.Е. Оценка уровня удовлетворенности качеством жизни. Водопьянова Н.Е. Психология здоровья. СПб.: Питер, 2005. С. 148-155.

3. Горбачевський В.К. Методика «Оцінка рівня домагань». URL: http://studcon.org/metodyka-vyvchennya-rivnya-domagan?page=1

4. Замфир К. Методика изучения мотивации профессиональной деятельности. URL: http://azps.ru/tests/tests2_zamfir.html

5. Коростылева Л.А. Психологические проблемы самореализации личности. URL: http://www.studmed.ru/nikiforovags-korostyleva-la-red-psihologicheskie-problemy-samorealizaciilichnosti-vyp-5_7cc47c56fd6.html

6. Лазукин А.В. Диагностика самоактуализации личности. URL: http://vsetesti.ru/195/

7. Максименко С. Д. Субъектный подход в изучении профессиональной самореализации. URL: http://psyjournals.ru/files/39330/ psyandlaw_2011_1_Maksimenko.pdf

8. Ричи Ш. Методика: Изучение мотивационного профиля личности. URL: http://www.hr-portal.ru/tool/metodika-izucheniemotivacionnogo-profilya-lichnosti-sh-richi-i-p-martin

\section{Information about the author: Kovalchuk Z. Ya.}

Doctor of Psychological Sciences, Professor, Vice Dean of the Faculty of Psychology Lviv State University of Internal Affairs 26, Gorodotska str., Lviv, 79007, Ukraine 